\title{
When Scotland Started to Speak (and Be Heard): UK and US Scottishness, 1934 and 1935
}

John Ritchie

\section{(2) OpenEdition \\ 1 Journals}

\section{Electronic version}

URL: http://journals.openedition.org/etudesecossaises/3569

DOI: 10.4000/etudesecossaises.3569

ISSN: 1969-6337

\section{Publisher}

UGA Éditions/Université Grenoble Alpes

\section{Printed version}

ISBN: 978-2-37747-275-8

ISSN: $1240-1439$

\section{Electronic reference}

John Ritchie, "When Scotland Started to Speak (and Be Heard): UK and US Scottishness, 1934 and 1935", Études écossaises [Online], 21 | 2021, Online since 31 March 2021, connection on 31 March 2021. URL: http://journals.openedition.org/etudesecossaises/3569 ; DOI: https://doi.org/10.4000/ etudesecossaises.3569

\footnotetext{
This text was automatically generated on 31 March 2021.

(C) Études écossaises
} 


\title{
When Scotland Started to Speak (and Be Heard): UK and US Scottishness, 1934 and 1935
}

\author{
John Ritchie
}

1 This article examines films produced in the UK and the US during the years 1934-5, each of which presents Scottishness in different manners. The commonly held belief after Scotch Reels intervention is that early cinema treated Scotland as a fantasy realm mixing either Kailyard or Tartanry (McArthur, 1982). Scotland was presented as being like that through the works and the global reach of writers such as Walter Scott and J. M. Barrie. The eighteenth and nineteenth century writers and novelists packaged and presented Scotland for the world and to the world in accordance with Hall's (1994, p. 402) concept of the imagined past, not the factual past. Following Sillars and Stenhouse (2008), this article appraises early sound cinematic representations of Scotland in order to assess whether productions from either side of the Atlantic can be seen as simply doing this or whether there were degrees of verisimilitude woven into the stories told. Does Kracauer's (1949, p. 53) assertion that Hollywood portrayals of foreign characters were simply "vague attitudes", which resulted in concrete types, stand true? Utilising contemporaneous reports as well as analysis of production and performance techniques the article examines four films: The 39 Steps (Hitchcock, 1935); The Ghost Goes West (Clair, 1935); What Every Woman Knows (La Cava, 1934) and The Little Minister (Wallace, 1934).

2 The 39 Steps (Hitchcock, 1935) is a loose adaptation of the novel of the same name, written by John Buchan. While on holiday in London, Richard Hannay becomes embroiled in an international spy ring. He soon finds himself on the run from the police who are seeking him for the murder of a spy, a murder he did not commit. He heads to Scotland and ends up hand cuffed to a woman who unwillingly accompanies him all the way back to London to solve the crime. Nicholas Haeffner $(2014$, p. 20$)$ notes that the film aims to fuse the spectacular with the visual and is a good example of a picaresque thriller. John Rossi (1982, p. 26) suggests that the film saw Hitchcock raise 
the chase-thriller to a new level of perfection and David Trotter states that "Hitchcock had found his niche by the time he made The 39 Steps" (2010, p. 116). Susan McCabe (2010, p. 129) claims that the film offers suspense and romance whilst capturing a distinctively British worldview.

3 The novel had been successful yet there are several differences between it and the film: in the novel Richard Hannay is a Scot who moved to South Africa at the age of six and has returned to the UK as an adult. In the film Hannay is described as being Canadian. ${ }^{1}$ The novel has an American male spy as the murder victim but the film changes this to a female, foreign freelance spy played by the German actress, Lucie Mannheim. Yet one of the largest differences concerns two characters, the Crofter and his wife. In Buchan's original work they exist only to allow Hannay to have somewhere to sleep for one night on his journey. In the film they exist to show a variety of things. James Morrison (2004, p. 207) suggests that Hitchcock's early British works use nationalities as MacGuffins. National identities are accepted by the viewer "as given, archetypal, universal rather than as local, distinctive" (ibid.). Is this really the case in The 39 Steps?

4 Robert Donat stars as Richard Hannay. Donat was, at that time, building a name for himself as an actor. He had had some success in the USA with The Count of Monte Cristo (Lee, 1934) to the extent that Michael Balcon, the producer of The 39 Steps felt that having Donat's name attached to the film would be advantageous in terms of appeal and marketing (Balcon, 1935, p. 27; Glancy, 2003, p. 28; Lowe, 2009, § 7). The film was generally well received by critics. The Monthly Film Bulletin magazine stated that it was "first-class entertainment" (January 1935, p. 72). A reviewer for Variety, using the penname "Jolo", declared that "yes, they can make pictures in England. This one proves it" (June 1935, p. 21). One of the few critics who did not enthuse about the film was Alastair Cooke who wrote in Sight and Sound in its summer edition, "this might have been an excellent film... but the story was never digested" (1935, p. 70). Cooke goes on to suggest that one of the film's problem areas is in its treatment of some of the more minor characters: "the attempt at odd, Capra-like pieces of inconsequent characterisation (the commercial travellers on the train, the milkman) are unobservant and academic" (ibid., p. 72).

5 The minor characters Cooke refers to are only loosely sketched. The milkman plays only one part in the story, to allow the audience to establish that Hannay will not be believed. The travellers on the train, two salesmen, serve to provide the first encounter with a Scottish character. It is entirely incidental to the plot but illustrates different attitudes that nationalities within the UK can have to each other. Arriving in Edinburgh, the salesmen wish to get a newspaper in order to find out the winner of a horse race. A paper boy is shown on the platform and one of the salesmen leans down to him and says: "Hey son, speaka da English?" We see Hannay roll his eyes at this man's treatment of the boy. The train leaves Edinburgh and one of the film's set-pieces occurs next: the escape from the police on the Forth Bridge.

6 The escape allows us to hear the first of several Scottish voices in the film. Donat's voice can be described as mid-Atlantic: well-spoken, vaguely British but not posh or with any specific regional accent. The early scenes of the film are a music hall setting with Cockney voices in abundance and in later scenes we are in a number of different Scotlands: the croft, the country house of the landed gentry and the Sheriff's office. Donat's voice allows him to stand out and move through the narrative in a similar manner to heroes of the western genre as identified by Kozloff (2000, p. 151): he can be 
understood by everyone in the film and he understands everyone in the film. The guard of the train berates the police for stopping the train (they pulled the emergency cord) and tells them in a Scots brogue that he, "cannae wait any longer!"

7 After his escape Hannay is seen walking across the country in the Highlands. He approaches a man, the Crofter, played by John Laurie whose performance in the film is noted in Land's review in Variety (18 September 1935, p. 15): "John Laurie as a grim, grasping, suspicious Scotsman gives a gem characterization [sic]." But this is a Scotsman new to the cinema: Laurie has a defined, layered character to portray. The film keeps the Crofter nameless but Hitchcock and Laurie present a Scotsman who is driven by money, the Kirk and power and who, in his final on-screen action, resorts to violence. $^{2}$

Scots characteristics of frugality and miserliness in the Crofter add a frisson of danger. Hannay asks if he can stay for the night; the Crofter's immediate retort is to ask, "For free?" Following a number of questions, the Crofter simply states to Hannay the price for staying: "Two and six." This is the first time that the Crofter looks Hannay in the eyes, exerting power over the stranger. Once the money has changed hands, the pair go to the croft where they are met outside by a woman (Peggy Ashcroft). Hannay asks if she is the crofter's daughter to which he receives the terse reply, "she's my wife", before the crofter stalks off.

For the Crofter, his wife is his property, his possession. There is little explanation as to why this young woman came to be living in a croft with this old man but there is a hint in her conversation with Hannay. We hear her say that she is from Glasgow. From her reactions to Hannay's conversation we see that she is unhappy and yearns to be in a city again, not in rural Scotland and most especially tonight as she talks of Glasgow being alive and vibrant on a Saturday night.

10 Hannay goes on to give her details of London (and tell her that she is more beautiful than the ladies there) before her husband returns. The Scottish woman is won over by the charming, intelligent foreigner, the mystery of the stranger sparking her desire to be free. Ashcroft and Donat give two marvellous performances in this section. She has a Scottish accent that only slips on occasion-she is let down by her non-native pronunciation of Glasgow and Sauchiehall-but is otherwise near perfect. Her longing for the glamour of the city are made clear by tiny reactions to Hannay's tales of city life. She wishes more than anything to not be with the crofter and sees Hannay as some form of escape either literal or vicarious. The croft itself is darkly lit and claustrophobic, a direct contrast to the only other domicile that has been seen on screen so far: Hannay's London flat. The flat is spacious and bright yet there are suggestions that Hannay is only a temporary resident (Glancy, 2003, pp. 46-7) whereas the croft has a permanence to it reminiscent of a prison cell which, for the Crofter's wife it is.

11 The conversation between the two is interrupted by the Crofter who returns and demands: "Woman, is the supper ready?" Their relationship is clear from this one line. The Crofter's wife is his servant. Another trait is then displayed by the Crofter: piety. Grace is said, and guidance sought from God in order that all three of them may be able to "continually turn our hearts from wickedness and from worldly things unto thee". The contrast with the wife's desire to be away from this place and this man lies uncomfortably. During the grace, Hannay realises that the wife knows from the newspaper that he is wanted for murder. As the two stare at each other they are 
unaware that the crofter is looking at the two of them. His eyes are lit as the focal point of the shot, there follows a close up of his face, his pronounced eyeballs darting between the two. That movement and camera angle show that he is utterly untrusting of their behaviour, the implication being that the Crofter fears that this young, handsome stranger is going to steal his young, pretty wife away from him. The style in this short section of film is an abrupt shift to German Expressionism, described by Mark Cousins as "Murnau-like" (2012, n.p.). The Crofter is a visual element that merges with the setting, the croft itself. Throughout the scene, John Laurie has heavy make-up on to accentuate his character's supposed age. ${ }^{3} \mathrm{He}$ is framed when looking through the window at Hannay and his wife in a manner that shows Hitchcock's expressionist experiences of working for UFA (Bordwell \& Thompson, 2013, p. 471).

The Crofter fits into two of Dyer's (2002, p. 11) clarifications of stereotype function: he exists as a short-cut and, more importantly for his character and actions, he expresses perceived values and beliefs. His frugality along with his piety are short cuts to "characteristic" Scottish behaviours taken by Hitchcock. More worryingly for representations of Scottishness the Crofter is shortly shown as being willing to resort to violence in order to control his wife.

Hannay leaves the croft abruptly. Realising that the police are on their way, Hannay attempts to bribe the Crofter by giving him five pounds to hide him. The Crofter goes to tell the police that Hannay is not here. Duplicity is now revealed by Hitchcock as a Scottish characteristic, particularly where money is concerned. The wife tells Hannay that he will just be stalling for time to find out if there is a reward for capturing him. Hannay is aghast at the deception of the Crofter: "But he took the money" he exclaims as the wife tells him not to be surprised by this action. The acceptance of this behaviour by the wife tells the audience that this is perfectly normal: if a Scotsman sees an opportunity for financial gain he will grasp it. This national trait is a given, an archetype that is universally accepted and exploited by Hitchcock here (Morrison, 2004, p. 207). In the hands of Hitchcock the demeanour here has elements of danger and ultimately signifies betrayal. The Crofter is most certainly not a character that could be described as being in what Lawrence Napper described as "the 'hoots mon!' tradition" (2009, p.6), a phrase that the use of alone indicates the strength of the comedic, stereotypical presentation of Scottish nationality.

The Crofter is seen in the police chase, as after all he now has a reward to chase for capturing Hannay, but disappears towards its end. He is only seen again once. Hannay is shot whilst wearing the Crofter's coat. Hitchcock cuts to the Crofter asking his wife if she has seen his hymn book, it was in the breast pocket of his best coat that was hanging on the peg beside him in the frame. His wife answers from off screen that she gave the coat to Hannay to help him escape. The Crofter's face wears an expression of thunder and he moves off screen towards his wife. We see nothing but hear an almighty slap and his wife scream which acts as a sound bridge to the next scene. The final impression of this Scotsman, the Crofter, is that of a savage who will beat his wife for misdeeds.

The Scottishness in The 39 Steps is stereotypical yet heightened in the character of the Crofter. The common traits of the Scotsmen are concerns with money and fear of the Lord. It is interesting to note though, that none of the Scottish characters are given names in the credits. The anonymity of these people is not truly important though; they are all plot devices, in common with Morrison's assertion that nationality is a 
MacGuffin. Scottish characters exist merely populating a series of vignettes that allow the hero to complete his journey and finish his tale.

By contrast, The Ghost Goes West (Clair, 1935) provides the first truly modern Scotsman in cinema. For the first time there is Scottish man as a lead character who is not continually dressed in tartan; who is not affiliated with the military; he is not suspicious of technology; he is not reliant on whisky and he is presented as a modern, urbane gentleman who understands etiquette and acts with decorum and dignity. The film also presents a unique look at what Duncan Petrie refers to as a "fundamental national identity crisis, expressed in the concept of the Caledonian antisyzygy" (2004, p. 135). The term Caledonian antisyzygy was first used by G. Gregory Smith in 1919 as a label to gather together the polar twins of literature-fantasy and realism (Carruthers, 2009 , p. 11). Laura O'Connor views the term as "a commingling of two contrary moods" (2005, §5), and in The Ghost Goes West it can be applied as the coming together of the past and the modern, with emphasis on the hold that the past has on the present. The basic plot of the film concerns an eighteenth century Scotsman (Murdoch Glourie, played by Robert Donat), killed in disgrace before a battle against the English army and condemned to walk the earth as a spirit until he can avenge himself, and his twentieth century descendant (Donald Glourie, also played by Robert Donat) who has inherited the family home and the ghost that haunts it.

17 The film was released in late 1935 and proved to be so successful that it was also the highest grossing British film in the UK in 1936 (Kuhn, 2002, p. 252; Gritten, 2008, p. 265; Alexander, 2014). Victoria Lowe notes that the importance of The 39 Steps for Donat was that it presented him as "a uniquely modern leading man" (2004, p. 119), but The Ghost Goes West presented Donat, playing Donald Glourie, as the first truly modern Scotsman on screen. The two performances by Donat stand in contrast to his work for Hitchcock. Whilst neither film can be regarded as particularly serious dramatic work, The Ghost Goes West allowed Donat to showcase not only his comedic abilities as a performer but also his ability to play a leading role that was markedly different from his last piece of work. Graham Greene's review of the film in The Spectator (December 1935, p. 1068) lavishes praise on Donat's performances of "invincible naturalness". Mark Forrest, writing in The Saturday Review, declared that "at the close of the year London Films has produced the best British film of it" (December 1935, p. 672). The director, the star and the film itself had a charmed existence with some areas of the British press. David Sutton $(2000$, p. 212) notes that the film is based on national stereotypes: the Scots in the early, modern section are penny-pinching, miserable and superstitious: Americans are brash, vulgar and have more money than sense. Two cultures clash in the film; the old world of tradition, history and clan feuds and the new world of commercialism and cultural vacuity. Sutton states that even given such well-worn themes and story elements, "the end result is one of the most charming and [...] genuinely sophisticated comedies of the decade" (2000, pp. 212-3).

The opening section of the film, set in the eighteenth century, lays out a number of Scots stereotypes: the passion for violence, the dislike of the English and the propensity to long running feuds with other Scottish clans. The introductory music is characteristically Scottish: the rhythmic thrum that is played is reminiscent of traditional Scots bagpipe pieces: it is a drone that has an interval of a fifth with a glissando to imitate the sound of the bagpipe's windbag priming. ${ }^{4}$ This builds in a major pentatonic scale from a drone to a lilting romantic melody. Pipes are featured and as 
the theme fades, it is pipes and drums that are left audible and the establishing shot after the titles is of a thistle, with the title "Scotland in the Eighteenth Century". The change in instrumentation from an orchestra to pipes and drums has located the film geographically as well as temporally.

Edward J. Fink's (2013, p. 48) positioning of stereotypes as part of the incongruity theory of comedy can be applied to the opening sequence of this film. Stereotyping can serve to provide a quick joke for an audience where time does not allow nuance or character development. The gentle humour that is characteristic of the film's attitude to the Scottish is shown here: as the McLaggens leave, the Glourie throws his whisky glass at the door after them. He is about to throw the bottle of whisky as well, in his rage, when he looks at it and instructs his attendants to "bring me anither glass", the line showing us the Scottish love of whisky but also has the first instance of a Scots word being used. The use of "anither" marks the first time a Scots word is heard and it is heard from one of the older characters. Scots is positioned by this as not only the language of the old in society but also confined to the past as nobody in the modern section of the film uses Scots words.

Murdoch is sent for and dispatched by his dying father to join the massed ranks of Scots preparing to fight the English and is tasked to find the McLaggen clan and make one of them kneel before him for insulting the Glourie name. "My son is a man at last, I can die contented" as the Old Glourie says, "when I've finished this whisky", which underlines the importance of whisky to the Scottish but also, as Fink would have it, uses a stereotype as a baseline for jest.

At the battle, Murdoch goes to retrieve a cannonball after the single Scots cannon, old Terrible, has misfired. As he is doing this we see the McLaggens being told of his presence and the Old McLaggen orders his sons to go and get Glourie. The feud is more important than fighting the English. A confrontation with the McLaggen sons ensues, he is chased back to the massed armies and hides behind a barrel of gunpowder which is blown up, taking Murdoch with it. His groom returns his hat to the castle (all that is left of Murdoch) and the ghost appears. The ghost's eyes are left unlit and in shadow by Clair, an unsettling visual of a man condemned to walk the castle until he can lift the curse. Murdoch's eyes are not seen in light again until after the castle has been moved from Scotland.

The modern section of the film begins with the Glourie home in a state of disrepair. Clair marks the transition with a fade from the castle as we last saw it to its dilapidated state. There is an aural change as well as the soundtrack of the film changes to jazz. The twentieth century Glouries are different: their name is no longer held in regard or esteem. The family has fallen on hard times and the last remaining member is being pursued by his creditors. Six of the creditors are seen in the kitchen of the castle discussing their situation with the cook. There is no tartan in sight but they are all concerned with money: one is owed $£ 150$ for ales, wines and liquors over the past seven years; another is due "upwards of $£ 200$ for provisions" and a third asks "what about my loan?"

Throughout the meal with the Americans, at which the creditors act as servants, there is a series of comic vignettes that poke fun at the Scots in terms of the pomposity of the old men and the expected behaviours of on-screen Scotsmen yet there is a lightness of touch and feeling that makes this comedic and gentle. This is not superiority humour as Sheila Lintott (2016, p. 347) explains it: the audience is not invited to laugh at the 
Scots or to feel superior to them in these scenes, rather it is a form of knowing pastiche.

Donald Glourie appears dressed formally for dinner. This means he is wearing, of course, a bonnie Prince Charlie jacket, waistcoat and bow tie along with kilt and sporran. Here the tartan is ceremonial. The host wears it, as do the pipers but the rest of the creditors (the staff) are dressed in evening wear of black tie code. This use of costume as occasional or ceremonial positions Glourie in the film as a modern Scot.

The characters' concern with money continues through the dinner. As Donald tells one of the men to open another bottle of champagne he is reminded that it costs twentytwo and six a bottle. The supporting Scots are played for comic effect. They are caricatures, men who are driven solely by money in one way or another. Donald Glourie is driven by the sale of the Castle to clear his debts, the creditors are driven by the sale of the Castle so they can get what is owed them. The Scots are painted with broad strokes, but played with a sense of light-heartedness throughout by the cast. It is in the treatment of the American characters that the humour becomes superior. Their lack of refinement and knowledge is shown by Mr Martin asking for more of the duck only to be told that it is grouse to which he simply responds, "well, what's the difference?"5

It is the relationship between the old and the modern that presents the division that the Caledonian antisyzygy embodies. Donald is literally cursed by his past, in the ghost of Murdoch, which follows him to the US with the castle. Ian Brown and Alan Riach $(2009$, p. 11) suggest that one function of the term is the split between the head and the heart of the individual. In this case the modern is the head where the past is the heart yet the two are ultimately seeking the same thing: resolution of their respective situations. The resolution comes when the modern helps the past to enact its vengeance and lift the curse, thereby freeing the present from the ghost of the past. An interesting moment in the dialogue comes when the two are conversing and Murdoch asks Donald if he fears him. Donald responds: “I haven't been afraid of you since I was five years old." The film can be read as suggesting that Scotland need not be afraid of the past but should accept it for what it is and be aware that it is irrevocably influential on the present.

The Scottishness in The Ghost Goes West is applied as a loving pastiche. There is good humour in its intentions once the initial establishment of the Scottish stereotypes has been dealt with. Donat's performances are remarkable. He provides two fully rounded characters who are both Scottish and manages to make each of them subtly different from the other. His accents are nearly flawless throughout. That does make his performances all the more noteworthy as he was the quintessential English gentleman of the screen at the time yet so effortlessly managed to pull off not one but two distinct Scottish voices in the film.

Noticeably fake accents create a sense of otherness and one way to counteract this is to develop the actor through vocal coaching (Holliday, 2015, p. 64). There is evidence that Hollywood developed actors' performances as the conversion to talkies solidified. Cynthia Baron (1999, p. 33) notes that in the early 1930s studios hired dialogue coaches or dialogue directors to work with actors and that these hired hands were an integral, if hidden, element of successful performances.

29 The Little Minister (Wallace, 1934) and What Every Woman Knows (La Cava, 1934) were based on works by J. M. Barrie. Forsyth Hardy (1990, p. 21), considering these two works, suggested that it would require considerable effort to find virtue in either of 
them. This is unnecessarily reductive of Hardy as both films have elements that are worthy of consideration and both have their own virtues. The star of The Little Minister, Katharine Hepburn, was establishing herself as a leading performer and went on to a long career but the film is rarely considered by critics and is usually confined to being mentioned in a footnote. What Every Woman Knows is even more rarely discussed, surprising perhaps given the lead in that was Helen Hayes, one of the bigger female stars of the time and widely regarded as one of the most important American actresses of the twentieth century.

What Every Woman Knows (La Cava, 1934) is based on a work by Sir James Barrie, this one originally a four-act play, published in 1908. This was the third production of a film version of Barrie's work and the second from the USA. The earliest production was made in the UK, directed by F. W. Durrant and starred Hilda Trevelyan, who had played Maggie in the original stage production in the same role. The second version, from the USA, was made in 1921, directed by William C. de Mille, and starred Lois Wilson as Maggie, although the first American to play Maggie was Maud Adams, on Broadway.

31 The cast of the 1934 version featured Helen Hayes as Maggie Wylie and Brian Aherne as John Shand. Hayes won the Academy Award for Best Actress in 1933 for her role in The Sins of Madelon Claudet (E. Selwyn, 1931). The Wylie family were played by David Torrence (Alick, the father), Donald Crisp (David, Maggie's brother) and Dudley Digges (James, Maggie's other brother). Lady Sybil, Shand's love interest, was played by Madge Evans and La Contessa la Brierre, Sybil's aunt, was Lucile Watson.

Barrie's play is based on a tale of the young man, John Shand, who has no education but wishes to receive one and enter politics. ${ }^{6} \mathrm{He}$ enters into an agreement with a Scottish family who say that they will fund his education on the condition that he marries the daughter, Maggie. He does so but upon arriving in London as an MP he is attracted to a society beauty. Maggie stands by him and he eventually returns to her, realising that she is the driving force and support that has taken him to the position he is in.

American reviews of the film were positive. Blackford, writing in The Billboard, noted that patrons who had prior knowledge of the play would enjoy the film, stating: "La Cava has given his cast authentic Scotch dialog and against the beautiful scenes of Scotland the picture unwinds as a scenic gem as well." (1934, p. 22) ${ }^{7}$ Abel, for Variety, praised the leads and noted that the supporting cast "exact the utmost from their assignments. Digges is particularly impressive" (1934, p. 16).

In the UK, Weir (1934, p. 5) noted that Barrie himself had made no comment on the film adaptation of one of his plays. ${ }^{8}$ Weir also notes that the cast perform admirably, saying that Hayes "has been ably schooled in the tackling of the "och awa' wi' ye" kind of speech; she makes a very sweet Scots lassie", and that Aherne and Digges, "both English, manage the ' $r$ ' commendably".

A more insightful review comes from Charles Davy (1934, p. 960) who draws attention to the translation of the work from the UK to the USA in stylistic terms. "All goes well with this American version of Sir James Barrie's play as long as the action stays in Scotland. The strains of 'Loch Lomond' do certainly threaten a rather too determined effort at picturesque atmosphere." Loch Lomond, used over the opening titles, is repeated at one point in the film: the family gather around the piano and Maggie plays. They all sing solemnly, dour and uncomfortable, as if only doing this out of a sense of duty. As a moment of performance it neatly conveys a family that is doing something because it is what is done, a tradition that nobody particularly enjoys but all feel they 
must partake in. This is one aspect of Kailyard represented in a physical form by the players: the unquestioning and accepting following of tradition. Weir notes another aspect of Kailyard in the film, that of the temporally located realm, in that the opening sequences, those set in Scotland "seem to belong in their whole atmosphere to a time before the war" (1934, p.5). The male members of the Wylie family are very much Kailyard inhabitants and played for comic effect.

The characterisation and accents of the male Wylies was also commented on by Collier, writing in The Picturegoer that "what will be thought of the accents in Scotland I am not Gaelic enough to hazard a guess" (1935a, p. 12). This point was reiterated when he noted that Hayes gave one of her best and most sympathetic performances, "in spite of the accent handicap". It fell to the anonymous writer for The Scotsman to note that "it is, perhaps, a minor critical point that the majority of the Scottish accents in the film defy recognition and that Maggie's in particular is distressingly vague" (ibid., p. 13). This is unfair. The accent used in the film is recognisable as a performed Scottish accent. This is most noticeable in the character of Alick (Torrence) who says "weel", rather than "well", and has over emphasised " $r$ "s. The rhoticism is carried on by the other members of the cast who are playing his family. Helen Hayes performs an accent that is a close copy of Torrence's. She notably rolls her "r"s in the words "broth" and "first", and uses clipped vowels as well as the native Scots actors. Hayes also, more intriguingly, changes her accent slightly when talking to the Contessa. This small moment of change reflects her ability as an actor: to change vocalisation when talking to people is a subconscious decision dependent on societal values and situation and Hayes accomplishes this with aplomb. Her realistic performance is, to borrow Baron and Carnicke's (2008, p. 183) term, transparent: the concrete aspect of performance elements are negated by her naturalism. We do not notice that she is acting the part.

Local Scottish newspaper reviewers were also full of praise for Hayes, and the film as a whole. Kinomer suggested the production did justice to Barrie's original work and that Hayes was "an actress of real sensitiveness and character" $(1935$, p. 3). The Evening Telegraph (1935, p. 10) in Dundee recognised that almost every time American filmmakers attempted to portray the Scots there were difficulties with characterisation and dialect yet the producers of What Every Woman Knows had surmounted these gracefully and that the film had "splendid acting and admirable casting".

The Little Minister (Wallace, 1934) is based on the play that was based on the novel of the same name by J. M. Barrie. There were four film versions of Barrie's tale made prior to this one: a 1913 Vitagraph short directed by James Young; a 1915 Neptune Film Company version, produced in the UK, directed by Percy Nash where Barrie is credited as the screenwriter; a 1921 version from Famous Players-Lasky Corporation and Paramount Pictures, directed by Penrhyn Stanlaws, and a 1922 Vitagraph production directed by David Smith.

The 1934 film stars Katharine Hepburn as Babbie and John Beal as Gavin Dyshart, the little minister of the title in his first major screen role. Radio Pictures chose The Little Minister as a vehicle for Hepburn to capitalise on her recent success in Little Women (Cukor, 1933). A large number of the cast was made up of Scots émigrés including Andy Clyde, Donald Crisp and Mary Gordon. Mary Gordon received press attention in the UK as the native Scot who was teaching Hepburn the dialect and was suggested for the role of "Nanny" by Hepburn as a result of this coaching (The Picturegoer, 1934). ${ }^{9}$ Gordon's work as the unofficial dialect coach was commented upon in a letter to The Picturegoer 
(Jolly, 1934), which, in addition to declaring that Hepburn as Babbie was "an excellent illustration of crazy Hollywood casting", also noted that Gordon's previous speaking roles had revealed a distinct Glasgow accent "which is as far removed from the Thrums dialect of Angus as the Oxford accent is from Cockney". ${ }^{10}$

The film itself is quietly remarkable in its treatment of Scottishness. The most striking stereotypes presented in the film are in the opening titles. The sequence feature a pastoral scene of a flock of sheep as the strains of Loch Lomond are heard. The lead cast are featured in separate titles, the actors' faces framed in a mirror placed on a swathe of brightly coloured tartan placed before a tartan backdrop. Expectations are set: the film will be awash with tartan as the main choice of clothing; Scottishness will be bursting forth from the screen at every opportunity.

But this does not happen. No character wears tartan exclusively or excessively. Mary Gordon, as Nanny, wears a tartan shawl but other than that there are no immediately noticeable costumed signifiers of Scottishness in the film. Men do not wear kilts. The minister himself dresses in the outfit of a nineteenth century Church of Scotland minister. His only adornment is a taller than normal top hat which he wears, in the film, to make himself seem taller. Hollywood here has dispensed with continual visual reminders of the setting and nationality of the characters in favour of setting up the film as being set in a "realistic" Scotland of the nineteenth century.

This presents an intriguing opportunity to examine the differences between Hollywood's treatment of Scottishness and UK critics' reactions to Barrie's work. Andrew Nash (1999, p. 77) notes that The Little Minister, in novel form, marked the change in critical response to Barrie as a realist. The romance between Babbie and Gavin was seen as improbable and unnatural; the introduction of high society figures into Barrie's works (Lord Rintoul) was taken as a step too far as there was a prevailing critical attitude that writers of fiction should draw their work from personal observation (Nash, 1999, p. 78). In other words, the source text was seen by UK critics as a flight of fancy that lacked the realism of Barrie's earlier works. The play, which the film was based on, had been highly successful in both the UK and the USA and did not differ from the novel in terms of its basic story, the romance between Babbie and Gavin. Barrie's work, perceived by UK critics as unrealistic, is accepted by the US filmmakers and audience as realistic. However, some Scottish critics were still not impressed with the adaptation. The Scotsman gave a preview of the film which suggested that the film had "definite virtues though they may be most apparent to those who do not expect strict faithfulness to Barrie" (1935a, 5 March, p. 13). This reinforces Naremore's note that critiques of adapted works are "inherently respectful of the 'precursor text"' $(2000$, p. 2).

But The Scotsman critic is not solely concerned with the perceived slight of Hollywood's disrespect for Barrie as the film itself is seen as accurate in its representations. The realism of the film is described as creating, "a Scottish-as distinct from a Barrieatmosphere" (1935a, 5 March, p. 13). He notes that "the scenes in the Auld Licht kirk at Thrums are entirely convincing", and that overall the film presents "a camera naturally recording glimpses of the life of the people" (ibid.). A preview by Collier in The Picturegoer echoed these sentiments: "the atmosphere of the Scottish village is excellently maintained as are the characters which go to make up its individuality" (1935a, p. 14). The performed 'real' Scottishness is commented upon but there is a note of caution in the approach taken by the writer who states: "I am not Scot enough to be 
hypercritical about the accents of the artistes, but taken as a whole I should say the general impression given, is entirely satisfactory."

Hollywood's representation of this 'real' Scotland struck a definite chord with the critical audience of the time. Lionel Collier described the film as "a wholly charming adaptation of Barrie's famous novel", and describing the Scottishness as possessing "fidelity" (1935b, pp. 24-5). The review in Dundee's The Evening Telegraph opens by stating that "Hollywood, entrusted with a Barrie play full of Scots wit and sentiment, makes a wonderfully authentic effort in The Little Minister" (1935, 10 September, p. 10). The Fife Free Press spoke of the attention to detail bringing the best out of Hollywood's resources $(1935,28$ September, p. 9) and The Scotsman, on 10 September 1935 in its review noted that "the little minister, the Egyptian wench, the gaunt Elders of the Auld Licht kirk, and the people of Thrums really do live in the film". The feeling of relief at Hollywood getting Scotland 'right' on screen is near palpable with The Kirkintilloch Herald praising the accuracy of the representation: "[...] no attempt was made to modernise it in any way and all the characters act, speak, and move in the little Scotch village of Thrums exactly as Sir James Barrie visualised them." (1935, 16 October, p. 5)

A large part of the credit for this should go to the Technical Advisor, Robert Watson. A Scotsman living in California and working in the film industry, he was interviewed in The Sunday Post in February 1935, where he reveals that he was asked to give would-be members of the cast a dialogue test in order to ascertain whether or not they could pass as Scottish in performance. The initial test was to "see if any of them could say Auld Licht Kirk convincingly and most said old Lickt Kurk" (p. 17), but Watson went on to reveal that if the performers were successful in their first attempt then they would, eventually, reach the final hurdle. This was to say the following: "Oot o'my sicht, ye glaikit kailrunt,that they made a polisman because they didna ken ye were deid. Ye're jist a dodderin dollop o' saultless parritch. G'wa hame, ye haverin body, afore I tell ye what I think o' ye." (Ibid.) ${ }^{11}$ Watson notes that in terms of accuracy of impression the honours went to Irishmen, then Americans and finally Englishmen. The test itself suggests that it was for supporting characters who would be following the Kailyard formula and speaking in Scots.

46 The film is ultimately the story of the romance of Babbie and Gavin, played by Katharine Hepburn and John Beal respectively. US critics saw the pair's performances positively. Writing in The Billboard, Blackford said that Hepburn "adds a certain touch of comedy to her lines that makes them fairly sparkle" (1934, p. 18), and that Beal "is a natural for such a role". Chic, in Variety, suggested that Hepburn's performance was excellent but noted that "there is little variety to her scenes due to the lack of plot complications" (1934, p. 18). Neither reviewer found any difficulty with the use of Scots in the film, a fact reflected and partially explained by the review in the Monthly Film Bulletin which notes that "much of the Scots dialect has been anglicised" (1935, p. 24).

Hepburn's accent is, for the large part, accepted by critics. Forrest notes that the Scottish accent is notoriously difficult to be accurate with and suggests that "though Katherine Hepburn's struggle with the demon is not too successful, the rest of the cast manages excellently" (1935a, p. 312). ${ }^{12}$ Collier felt that Hepburn was "brilliant as Babbie" (1935b, p.14), and goes on to explain that part of the justification of this statement is that Hepburn, as Babbie, plays dual roles in the film. Babbie is both a wild gypsy woman and the refined ward of Lord Rintoul. As such she changes her accent and use of language to suit the social situation that she is in, yet this also has the effect of 
reinforcing societal differences between characters (Kozloff, 2000, p. 27). In the company of Lord Rintoul, Babbie speaks with more care of pronunciation and fewer glottal stops yet when she is in the company of Nanny she speaks in the same manner as Nanny. This facet of Babbie's character is noted as an allusion to the mystery that surrounds her: Doctor McQueen, played by Donald Crisp, asks Gavin, "Who could she be? You saw how easily she took the Scotch tongue on and off?" as Babbie has just persuaded the Doctor not to evict Nanny to the poor house. This element of Hepburn's performance of Scottishness is naturalistic and effortless. In the scene, there are two native Scottish actors (Crisp and Gordon) and two American actors (Hepburn and Beal) and all of them are playing Scottish characters. What is noticeable is the emphasis that Crisp and Gordon use in their voices in order to naturalise Hepburn's. Both Scottish actors use exaggerated rhoticism in their speech which mirrors Hepburn's accent. As all of the actors are using very similar accents there is no sense of any natural difference in the characters; it is when Hepburn modifies her voice to address Nanny directly that this change occurs but this is, of course, a plot point anyway. All of this points to Hepburn giving an assured and controlled performance that fits the diegesis and is accurate.

Scottishness in The Little Minister is presented as an element of the story: it is set in Scotland and there is no emphasising or overtly ostensive attempts to highlight this. The use of costume is restrained and grounded in reality. Characters and situations are presented with a degree of verisimilitude that is lacking in earlier US productions and the lead performer gives an assured and controlled performance that elegantly and simply presents a Scottish woman.

This examination of early sound cinema's relationship with Scotland shows that one of the more lauded directors of film history, Alfred Hitchcock, presented the Scot as a figure that was to be feared. The Crofter, is simply out for all that he can get. Hitchcock immerses him into the environment of the film with the effect that although he only has a short period of time on screen he is easily the most memorable of the characters on the hero's journey. Laurie's performance of the perfidious, pious creature is magnificent. Turning from drama, Stenhouse's assertion regarding the banal or kitsch being ignored needs to be addressed: The Ghost Goes West can be seen in Alloway's terms (1958, p. 84) as being kitsch, it was popular at the box office and it was a comedy. All factors which would mark it out as unworthy of critical attention to some. However, it does present Scottishness in a mature and progressive manner. The idea that Clair's film stands up to challenge Caledonian antisyzygy stems directly from Stenhouse's statement that texts, however trivial or jocular they may be on the surface, can offer new avenues of thought. Reductive critiques, à la Scotch Reels, miss the opportunity to analyse the popular at the cost of identifying stimulating presentation of ideas within a text. The Little Minister indicates that the film, and the central performance by Katharine Hepburn, has been unjustly maligned whilst the skills of the supporting cast has been roundly ignored. The same can be applied to Helen Hayes and support in What Every Woman Knows. Both films stand above other US representations of Scottishness through the lack of cliché and stereotype in their presentation. Scotland, the Scottish people and the country are accepted within the films as real locations and real people. But it is the content of the pieces that speak of a more relaxed attitude to presenting Scottishness: an attitude that does not poke fun at the people or the tales told in the 
films but simply presents Scotland and Scottishness as a given. For once, Hollywood did lead the way in true representations.

\section{BIBLIOGRAPHY}

ABEL, 1934 (30 October), "Film Reviews: What Every Woman Knows", Variety (Archive: 1905-2000), vol. 116, no. 16. Available on <https://search.proquest.com/docview/1475880961>.

AleXANDER Lou, 2014, “The Ghost Goes West (1935)”, BFI Screenonline. Available on $<$ www.screenonline.org.uk/film/id/453810/>.

AllowAY Lawrence, 1958, “The Arts and Mass Media”, Architectural Design, vol. 28, no. 2, pp. 84-5.

“Around the Local Cinemas", The Fife Free Press, 1935 (28 September), p. 9.

BALCON Michael, 1935 (26 January), "British Pictures for the World", Picturegoer (Archive: 19321960), vol. 4, no. 26-27. Available on <https://search.proquest.com/docview/1771192032>.

BARON Cynthia, 1999, “Crafting Film Performances: Acting in the Hollywood Studio Era”, in A. Lovell and P. Krämer (eds), Screen Acting, London, Routledge, pp. 31-45.

BARON Cynthia \& CARNICKE Sharon Marie, 2008, Reframing Screen Performance, Ann Arbor, University of Michigan Press.

BLACKFORD, 1934a (29 December), "Motion Pictures: From The Box-Office Point of View - The Little Minister", The Billboard (Archive: 1894-1960), vol. 46, no. 18. Available on <https:// search.proquest.com/docview/1032061778>.

BlACKFORD, 1934b (20 October), "Motion Pictures: From The Box-Office Point of View - What Every Woman Knows", The Billboard (Archive: 1894-1960), vol. 46, no. 22. Available on <https:// search.proquest.com/docview/1032047362>.

BoRdWell David \& THOMPson Kristin, 2013, Film Art: An Introduction (10th ed.), New York, McGrawHill.

BRocketT Lenyth \& BRocketT O. G., 1958, “J. M. Barrie and the Journalist at His Elbow”, Quarterly Journal of Speech, vol. 44, no. 4, pp. 413-22. Available on <https://doi.org/ 10.1080/00335635809382322>.

BRown Iain \& RiAcH Alan, 2009, “Introduction”, in I. Brown \& A. Riach (eds), The Edinburgh Companion to Twentieth-Century Scottish Literature, Edinburgh, Edinburgh University Press, pp. 114.

BRoWNRIGG Mark, 2007, "Hearing Place: Film Music, Geography and Ethnicity”, International Journal of Media and Cultural Politics, vol. 3, no. 3, pp. 307-23.

CARRUTHERS Gerard, 2009, Scottish Literature, Edinburgh, Edinburgh University Press.

CHIC, 1935 (1st January), “Film Review: The Little Minister”, Variety (Archive: 1905-2000), vol. 117, no. 18. Available on <https://search.proquest.com/docview/1475856971>. 
Collier Lionel, 1935a (5 January), "Pre-Views of the Latest Films: Helen Hayes Goes Scottish", Picturegoer (Archive: 1932-1960), vol. 4, no. 12-13. Available on <https://search.proquest.com/ docview/1776934544>.

COLLIER Lionel, 1935b (16 March), "Pre-Views of The Latest Films: Let Our Critics Who Really See The Films Guide You: Another Hepburn Triumph", Picturegoer (Archive: 1932-1960), vol. 4, no. 14-15. Available on <https://search.proquest.com/docview/1771191783>.

COOKE Alistair, 1935 (Summer), "Films of the Quarter", Sight and Sound, vol. 4, no. 70. Available on <https://search.proquest.com/docview/1305501525>.

Cousins Mark, 2012, The Story of Film [Kindle DX version]. Available on <www.amazon.co.uk>.

DAvy Charles, 1934 (21 December), “The Cinema: What Every Woman Knows at the Empire”, The Spectator, p. 960.

DYER Richard, 2002, The Matter of Images: Essays on Representation, London, Routledge.

DYER Richard, 2007, Pastiche, London, Routledge.

FinK Edward, 2013, "Writing The Simpsons: A Case Study of Comic Theory", Journal of Film and Video, vol. 65, no. 1-2, pp. 43-55.

FORREST Mark, 1935a, “Cinema: The Little Minister", Saturday Review of Politics, Literature, Science and Art, vol. 159, no. 4141, p. 312. Available on <https://search.proquest.com/docview/9332396>.

FORREST Mark, 1935b (December), “Cinema: The Best British Film of the Year”, Saturday Review of Politics, Literature, Science and Art, vol. 160, no. 4186, p. 672. Available on <https:// search.proquest.com/docview/9391150>.

GLANCY Mark, 2003, The 39 Steps, London, I. B. Tauris \& Co. Ltd.

GREENE Graham, 1935 (27 December), “The Ghost Goes West at the Leicester Square. Foreign Affaires at the Capitol (Book Review)”, The Spectator, vol. 155, no. 1068. Available on <https:// search.proquest.com/docview/1295649049>.

GritTEN Daniel, 2008, “'The Technique of the Talkie': Screenwriting Manuals and the Coming of Sound to British Cinema", Journal of British Cinema and Television, vol. 5, no. 2, pp. 262-79.

HAEFFNER Nicholas, 2014, Alfred Hitchcock, Abingdon, Routledge.

HALL Stuart, 1994, "Cultural Identity and Diaspora”, in P. Williams and L. Chisman (eds), Colonial Discourse and Post-Colonial Theory: A Reader, London, Routledge, pp. 227-37.

Holliday Christopher, 2015, “The Accented American: The New Voices of British Stardom on US Television”, Journal of British Cinema and Television, vol. 12, no. 1, pp. 63-82.

Jolly David D., 1934 (24 November), "What Do You Think? Letters from Our Readers: Little Minister Casting”, Picturegoer (Archive: 1932-1960), vol. 4, no. 34. Available on <https:// search.proquest.com/docview/1771190346>.

Jolo, 1935 (19 June), “Film Reviews: The 39 Steps", Variety (Archive: 1905-2000), vol. 119, no. 21. Available on <https://search.proquest.com/docview/1475885752>.

KINOMER, 1935 (27 April), "Next Week on the Screen: Film-Makers Rediscover Sir J. M. Barrie”, The Evening Telegraph, p. 3.

Kozloff Sarah, 2000, Overhearing Film Dialogue, Berkeley, University of California Press. 
KRACAUER Siegfried, 1949, "National Types as Hollywood Presents Them", The Public Opinion Quarterly, vol. 13, no. 1, pp. 53-72.

KuHN Annette, 2002, An Everyday Magic: Cinema and Cultural Memory, London, I. B. Tauris \& Co. Ltd.

LAND, 1935 (18 September), “Film Reviews: The 39 Steps”, Variety (Archive: 1905-2000), vol. 120, no. 15. Available on <https://search.proquest.com/docview/1475920281>.

LinToTT Sheila, 2016, "Superiority in Humor Theory", The Journal of Aesthetics and Art Criticism, vol. 74, no. 4, pp. 347-58.

LOWE Victoria, 2004, The Matinee Idol and the False Beard: Performance and Stardom in the Films of Robert Donat, 1934-1940, Doctoral dissertation, University of Manchester.

LowE Victoria, 2009, “'Performing Hitchcock': Robert Donat, Film Acting and The 39 Steps (1935)”, Scope - An Online Journal of Film and TV Studies, vol. 2009, no. 14. Available on <www.scope.nottingham.ac.uk/article.php?issue=14\&id=1139>.

McARThUR Colin, 1982, Scotch Reels: Scotland in Cinema and Television, London, British Film Institute.

MCARTHUR Colin, 1982, "Scotland and Cinema: The Iniquity of the Fathers", in C. McArthur (ed), Scotch Reels: Scotland in Cinema and Television, London, British Film Institute, pp. 40-69.

McCABE Susan, 2010, “The British Hitchcock: Epistemologies of Nation, Gender and Detection”, Modernist Cultures, vol. 5, no. 1, pp. 127-44.

MORRISON James, 2004, “Hitchcock's Ireland: The Performance of Irish Identity in Juno and the Paycock and Under Capricorn", in R. Allen and S. Ishii-Gonzales (eds), Hitchcock: Past and Future, London, Routledge, pp. 193-210.

NAPPER Lawrence, 2009, British Cinema and Middlebrow Culture in the Interwar Years, Exeter, University of Exeter Press.

NAREMORE James, 1988, Acting in the Cinema, Berkeley, University of California Press.

NASH Andrew, 2007, Kailyard and Scottish Literature, Amsterdam, Rodopi.

PeTRIE Duncan, 2004, Contemporary Scottish Fictions: Film, Television and the Novel, Edinburgh, Edinburgh University Press.

Rossi John, 1982, “Hitchcock's Foreign Correspondent (1940)”, Film \& History: An Interdisciplinary Journal of Film and Television Studies, vol. 12, no. 2, pp. 25-35.

"Scots Test That Stumped Hollywood", The Sunday Post, 1935 (24 February), p. 17.

SILlARS Jane, 2008, “Admitting the Kailyard”, in J. Murray, F. Farley, and R. Stoneman (eds), Scottish Cinema Now, Newcastle, Cambridge Scholars Publishing, pp. 122-38.

STENHOUSE David, 2008, "Not Made in Scotland: Images of the Nation from Furth of the Forth", in J. Murray, F. Farley, and R. Stoneman (eds), Scottish Cinema Now, Newcastle, Cambridge Scholars Publishing, pp. 171-87.

SuTTON Dudley, 2000, A Chorus of Raspberries: British Film Comedy 1929-1939, Exeter, University of Exeter Press.

“The Cinema: Scotland and Barrie Films", The Scotsman, 1935 (5 March), p. 13.

“The Cinema: The Little Minister", The Scotsman, 1935 (10 September), p. 6.

“The Picture Houses", Kirkintilloch Herald, 1935 (16 October), p. 5. 
“The Thirty-Nine Steps", Monthly Film Bulletin, 1935 (1st January), vol. 2, no. 72. Available on <https://search.proquest.com/docview/1305799605>.

TrotTer David, 2010, “Hitchcock’s Modernism”, Modernist Cultures, vol. 5, no. 1, pp. 106-26.

WEIR Andrew, 1934 (17 November), “Another Barrie Film: Helen Hayes in What Every Woman Knows", The Leeds Mercury, p. 5.

“With Katharine Hepburn on Location", Picturegoer (Archive: 1932-1960), 1934 (3 November), vol. 4 , no. 9. Available on <https://search.proquest.com/docview/1771188127>.

\section{NOTES}

1. There is no concrete evidence to support a reason for this change in the character's origin. Robert Donat does not use a Canadian accent in the film, his voice is a neutral mid-Atlantic, the point of the character of Hannay being that he is an outsider who is tossed into events that change his life so the neutral voice is well suited to lend an air of everyman to the character. Hannay's origin is mentioned in a throwaway line at the beginning of the film when Mr Memory answers a question posed by Hannay about the distance from Winnipeg to Montreal. Mr Memory simply says, "Ah a gentleman from Canada" before giving the correct answer. It is possible, as suggested to me by Mark Glancy, that the change in nationality from Scots to Canadian is simply alluding to Buchan himself who was appointed as Governor-General of Canada in 1935.

2. The character is in the credits as "Crofter" and his wife is listed as "Crofter's Wife" although in dialogue the wife refers to the Crofter by the name, "John".

3. There is a clear implication in the film that the Crofter is much older than his wife, when he is mistaken by Hannay for her father. John Laurie was in his mid-30s at the time of filming, only some ten years older than Peggy Ashcroft and around eight years older than Donat.

4. Mark Brownrigg (2007, p. 320) noted this distinctive musical characteristic as being used in many large budget Hollywood films of the 1990s, particularly Braveheart.

5. The Scottish obsession with money immediately comes back to play here as the provisions merchant, who is the waiter, replies "eleven shillings and eight pence".

6. The political material for the play was based on Barrie's first-hand observation of the campaign of A. E. W. Mason who ran for Parliament in Coventry in 1906 (Brockett \& Brockett, 1958, p. 416).

7. Blackford's review, the comments about the scenic aspect of Scotland in the film are puzzling. The film only uses one exterior location which is meant to be the railway station in the fictional Borders town of Kilburnie and the station used is not in keeping with the architectural style of railway stations of the early twentieth century. It is, in fact, barely glimpsed as La Cava keeps his framing tight around the actors in all the scenes that feature the station.

8. The film is credited in the opening titles as being by "Sir James Barrie", but the continuing titles reveal that the screenplay was written by three people: Monckton Hoffe, John Meehan and James K. McGuinness.

9. Mary Gordon had been working on stage and screen in the USA for some time and had appeared in Annie Laurie, Seven Days Leave, The Black Watch (in a comic vignette as the soldiers are leaving for France she plays Sandy's wife) and many other films in mostly uncredited supporting roles. She went on to portray Mrs Hudson in the Sherlock Holmes films starring Basil Rathbone as the sleuth.

10. The writer of the letter went on to suggest that, in his opinion, Scottish characters could only be played by "great screen actresses", and that the producers of the upcoming biopic of Mary 
Stuart should approach Greta Garbo to play the title character. That part that subsequently went to Katharine Hepburn.

11. This translates as: "Get out of my sight you stupid, worthless person, who was made a policemen by those that did not realise that you are so dim as to be nearly dead. You are nothing but an ineffectual lump of inedible porridge. Now go home, you dim-witted fool, before I tell you what my actual opinion of you is."

12. Forrest also reviewed Seven Days Leave yet makes no comment about accents in that film-he reserves his ire there for adapting Barrie, a tact that he does not use on this occasion.

\section{ABSTRACTS}

This paper researches representations and performances of Scottishness in UK and US cinema from 1934 and 1935. Utilising archive material in tandem with performance analysis this paper addresses questions of verisimilitude in these productions.

The UK presents two very different Scotlands and different people. A Scotsman to be feared, savage and pious and afraid of outsiders in Hitchcock's The 39 Steps is juxtaposed against the first truly modern screen Scotsman in Clair's The Ghost Goes West.

The US present adaptations of two of J. M. Barrie's works, What Every Woman Knows and The Little Minister. Two films led by female characters, the US productions put the idea of a 'real' Scotland at their core.

The paper concludes with a surprising revelation regarding verisimilitude in executions of performed Scottishness.

INDEX

Keywords: Scottishness, performance, sound, stereotype, verisimilitude

\section{AUTHOR}

JOHN RITCHIE

University of Stirling

john.ritchie@stir.ac.uk 